\title{
Student Well-Being in Online Learning during the Covid-19 Pandemic: Voice in the Field
}

\author{
Suyatno $^{1}$, Wantini $^{2}$, Zalik Nuryana ${ }^{3}$, Ali Mu'tafi $^{4}$, Mochamad Iskarim $^{5}$, Febiana Kornelia Wu ${ }^{6}$
}

\begin{abstract}
Online learning during the covid-19 pandemic has resulted in psychological impacts on students, such as stress, fear, anxiety, depression, and burned out. Many literatures relevant to the issue have mentioned that student well-being proves to be one of the influencing components of a student's success. However, being a significant factor, no research has related student well-being with online learning during the covid-19 pandemic. The current study explored the students' experience in determining the aspects influencing their wellbeing in online learning during the pandemic to fill in the gap.The data were gathered through an interview with 12 senior high-schoolers who have attended online learning for one year in Yogyakarta City. The study, employing interpretative phenomenology, found that the student well-being is established from several factors. For example, the teachers are aware and concerned, the learning is enjoyable and less burdening, and the peers are fun and supportive. The findings can be used as a reference for teacher training institutions (LPTK), principals, and teachers to improve student well-being during online learning.
\end{abstract}

Keywords:Student well-being, online learning, covid-19, student's voice

\footnotetext{
${ }^{1}$ Dr., Universitas Ahmad Dahlan, Faculty of Teacher Training and Education, Department of Education Management, suyatno@pgsd.uad.ac.id, https://orcid.org/0000-0002-5796-6100

${ }^{2}$ Dr., Universitas Ahmad Dahlan, Faculty of Islamic Religion, Department of Islamic Education, wantini@mpai.uad.ac.id, https://orcid.org/0000-0003-2896-0559

${ }^{3}$ Dr. (Cand.), Nanjing Normal University China, School of Education and Science, zalik@ ascee.org, 0000-00018701-0487

${ }^{4}$ Dr. (Cand.), Universitas Sains Al-Quran Wonosobo, Faculty of Teacher Training and Education, Department of Islamic Education, alimutafi@unsiq.ac.id, https://orcid.org/0000-0002-9145-8521

${ }^{5}$ Dr. (Cand.), IAIN Pekalongan, Faculty of Teacher Training and Education, Department of Islamic Education, iskarim@iainpekalongan.ac.id, https://orcid.org/0000-0002-4172-5038

${ }^{6}$ Graduated student, Universitas Ahmad Dahlan, Faculty of Teacher Training and Education, Department of Education Management, febianakorneliawu@gmail.com, https://orcid.org/0000-0001-5879-1915
}

Received: 22.06.2021, Accepted: 26.06.2021 


\section{Introduction}

The shift of learning platform from face-to-face to online as one effect of the covid-19 pandemic(Favale et al., 2020;Kim, 2020;Zimmerman, 2020;Vijay Govindarajan \& Anup Srivastava, 2020;UNESCO, 2020)has affected several parties, such as school management, teachers, parents, and students(Adedoyin \& Soykan, 2020;Baticulon, 2021; Bozkurt \& Sharma, 2020;Oktaria \& Rahmayadevi, 2021;Pokhrel \& Chhetri, 2021;Ribeiro, 2020). As a result, most students experienced psychological and emotional pressure. Besides, they cannot engage productively in the learning process. Indeed, in most developed countries, online learning brings many obstacles, such as limited access to online learning devices for students(Daroedono et al., 2020; Fedynich, 2014; Fishbane\& Tomer, 2020; Pokhrel \& Chhetri, 2021; Mukhtar et al., 2020;Wedenoja, 2020), inadequate infrastructure and technical support, teacher's low commitment(Frehywot et al., 2013), resistance towards change (Childs et al., 2005), and inadequate supports from the institution(O'Doherty et al., 2018). Less interaction with students (Öztürk, (2021), closeness, attachment, and opportunities to consult with the teachers directly can decrease the students' learning achievement (Sintema, 2020).The worst, online learning from home increases the potential of violence towards children(Ravichandran \& Shah, 2020).

Apart from the challenges and negative impacts, online learning should provide a chance for improvement for educational practices globally(Adnan \& Boz, 2015;Astuti et al., 2021;Hidayati \& Saputra, 2020; Ryan \& Deci, 2020; Whalen, 2020; Zakaria, 2021).Several authors mentioned the advantages of online learning. For example, it is flexible(Smedley, 2010), faster(Wagner et al., 2008), and interactive(Leszczyński et al., 2018). Besides, online learning does not depend on physical location.All people can participate and join the learning since it is cost-effective(Fedynich, 2014;Yilmaz, 2019). Further, several studies mentioned that online learning is better than traditional one(Barboni, 2019; Means et al., 2013).Therefore, during the pandemic, the concern is not about quality learning. Instead, it is how the academic institution adopts online learning for massive needs and all people's comfort(Carey, 2020).

Several studies have discussed the process of online learning.Baticulon (2021)studied the obstacles experienced by medical students in online learning in a developed country. The electronic survey of 3760 medical students concluded that they experienced some difficulties, such as adjusting the learning style. Besides, they are unable to focus on learning because they have to do the housework simultaneously.Poor communication between the educators and the learners also adds to the difficulties. Kim(2020)conducted a descriptive study about the need to change the courses for early childhood education teachers in the United States of America due to the covid-19 pandemic. The redesign focused on improving the teachers' skills in utilizing information and technology in online learning. He explained the three phases of redesigning the course: preparation, implementation, reflection. The new design is expected to allow teachers to interact with the children. Besides, it encourages them to reflect on the best way to promote a child's development and instruction using online 
communication devices. Another research by Chiu (2021)investigated the importance of students' engagement during online learning. Engagement, encouraged by motivation as exemplified in the self-determination theory (SDT), becomes one requirement in learning. Using pre-and post- questionnaire filled in by 1201 students, the research showed that the students' needs are more sufficed by digital support. Other than the above research, another one about online learning implemented due to other reasons have been published. For example, the research found that students were not ready to balance the job, family, social life, and learning environment(Parkes et al., 2015). Many students and teachers experienced psychological problems, stress, fear, anxiety, depression, and insomnia, preventing them from focusing and concentrating on the learning process(Di Pietro, 2018).

One aspect that cannot be ignored to support the students' success in online learning is student well-being. It has become the current conceptualization ofeducational goals(Domitrovich et al., 2017). Student well-being is a psychological aspect necessary in the online learning implementation. It influences the students' comfort, well-being, and learning success. Several studies showed that well-being could increase health (Diener \& Chan, 2011)and performance(Wright \& Cropanzano, 2000). Student well-being is a multidimensional construction that includes the school's condition, emotion, and positive reality(Scrimin et al., 2016;Tuominen-Soini et al., 2012).MeanwhileLan and Moscardino (2019)andZins and Elias (2007)mentioned that student well-being consists of students' engagement in academic activities, satisfaction toward the relationship with peers, and commitment toward the school. Well-being is the main predictor of students' motivation, engagement, and achievement(Fogarty et al., 2014;Lewis et al., 2011; Seligman et al., 2009). Martin (2020)explained that motivation, relationships, and mental health are crucial in implementing online learning. Although student well-being is significant in optimizing the learning process during face-to-face settings, it is neglected in the online situation due to the pandemic. To fill in the gap, the current study explored the students' experiences in finding the aspects that can establish their well-being during online learning in the pandemic. The phenomenology approach employed in the research enables the data exploration from the students to reveal their experience in their perspective(Creswell, 2013; Sweetman et al., 2010).

\section{Research questions}

What are the students' experiences in attending online learning during the covid-19 pandemic and what aspects can develop their well-being?

\section{Methodology}

The research adopted the qualitative method to summarize the participants' experience in their natural setting, leading to rich and substantial information regarding the phenomena under study(Creswell, 2012;Patton, 2002). Interpretative phenomenology approach was 
employed as suggested by Langdridge(2007)and Smith et al. (2009). As Smith and Osborn (2008, 2015) proposed, Interpretive Phenomenological Analysis (IPA) is one way to analyze the qualitative data appropriately. In particular, it is to understand the research topics loaded with emotional aspects. IPA orients toward obtaining in-depth and textured personal and subjective meanings shared by the individuals based on their experience in all aspects of their life(Brooks et al., 2017; Larkin et al., 2006; Smith et al., 2009; Wedlock, 2016). The approach offers detailed analysis, evaluating each case based on the ability before moving to a more general cross-case for the convergence and divergence among cases(Smith et al., 2009).

\section{Participants}

In line with the research objective, the homogenous samples were selected(Noon, 2018). A criteria-based purposive sampling technique (Bhanot \& Verma, 2020)was employed to identify and select the participants who attended the online learning for a year. It was to ensure that the participants have gained adequate experiences, enriching the data(Noon, 2018). The research resource was 12 students from one of the private schools in Yogyakarta City. They consisted of 7 female and 5 male students, aged from 17 to 19 years old. The respondents' names were represented by codes P1-P12 for the sake of confidentiality(Iqbal et al., 2020). The research followed the ethical guidelines proposed by the American Psychological Association (APA). All participants joined the research voluntarily. Before deciding to take part in the research, they were given adequate information about the research background and objectives.

\section{Data Collection and analysis}

The data were gathered through a semi-structured interview(Smith et al., 2009).It develops an in-depth understanding of the participants' experience. It createsan interactive dialog between the participants and the researchers(Modesto, 2020).In gathering the data, interview guidelines were employed. The instrument was in the form of non-directive open-ended questions based on the expectation towards the participants related to the research objectives(Smith\& Osborn, 2008, 2015). The interview guideline was developed based on the aspects of student well-being as explained in the background of the study. Before it was used, the guideline was consulted by an expert. After revision following the expert's suggestions, the guideline was then utilized. In practice, the guideline was employed in a flexible manner(Iqbal et al., 2020). The followings are the sample questions are given to the students: 1) What is your experience in attending online learning for about a year? 2) How do you engage in academic activities at school? 3) How is your relationship with teachers and peers in the school during online learning? And 4) What aspects make you satisfied and willing to participate more in the online learning activities during the covid-19 pandemic?

The data were analyzed through IPA data analysis steps, as suggested byNoon (2018). First, the researchers tried to developan in-depth understanding of the informants' unique 
experiences about the phenomena under the study(Cassidy et al., 2011).After that, the themes were extracted individually into broader themes(Smith\& Eatough, 2006).Finally, the existing themes and homogeneity were categorized conceptually (Smith \& Osborn, 2008).In presenting the research results, quotations from the relevant interview were included to support each theme.

\section{Findings}

Through IPA data analysis, three important themes were established based on the research informants' responses. They are care and concerned teachers, enjoyable and less burdening learning, and fun and supportive peers. The themes were explained supported by the relevant quotes from the interview.

\section{Care and concerned teachers}

The respondents mostly mention the care and concerned teachers in terms of their well-being during online learning. All respondents $(n=12)$ stated that well-being is established when the teachers care for them during online learning. Therefore, the topic presents in the following codes: my teacher notices me, my teacher cares for my problem, and my teacher is friendly. For example, P1 explained that it is fun to learn at school because the teachers pay attention to the students.

Mrs. [teacher's name] always supports and encourages me. The virtual learning activities are less burdening, and it feels like time flies so fast. Although I don't like physics, taught by Mrs. [teacher's name] changes the way I think about it (P1, 37-40).

P8 shared the same experience. The student mentioned that the learning motivation is maintained during the pandemic. The teachers always encourage the students and give them advice and suggestions. They also spare their time to listen to the students' problems.

Because they always motivate me when something terrible happened or when I don't feel I want to do anything. When I pour my heart out, they are willing to listen and give me advice and suggestions to make the situation better (P8, 1518).

A similar experience was also shared by P9. For the student, the attention given by the teachers at school can maintain the enthusiasm to keep learning even in the problematic condition during the pandemic.

Both teachers [teacher's name] gave me the opportunity to have a new experience that I've never felt before (P9, 80-81). They also respond to a problem patiently and positively; they immediately find a way out for the problem. With Mrs. 
[teacher's name], I can express what I feel. When I need to use the school facilities or want to do something, then I told her, she always listens and gives me alternative solutions for what my friends and I can do next (P9, 97-101).

The teachers' awareness helps P10 to maintain enthusiasm and engagement in the learning process during the covid-19 pandemic.

Mrs. [teacher's name] always asks, "Nduk [ways of addressing female child in Yogyakarta], what happened?" "Nduk, is everything okay?" "Nduk, I know you are strong." For many reasons, those kinds of questions help me stay here and attend the learning process during the covid-19 pandemic. I feel cared for by the teachers (P10, 24-27).

The events told by the students showed that concern, attention, kindness, and flexibility are crucial in maintaining the students' motivation to engage in the learning process. Further, they feel satisfied with the school services.

\section{Enjoyable and less burdening learning}

Enjoyable and less burdening learning during the covid-19 pandemic becomes essential for students. Most of the students $(n=10)$ shared their experiences during the learning process. They mentioned that the learning is fun, exciting, manageable, and comprehensible. The condition helps to maintain their learning enthusiasm and satisfaction with the school services. One of the respondents, P3, has a unique experience. The student feels that the learning experience in high school is much more different from when the student was in the previous educational levels. The student mentioned that learning in the classroom was something horrible, worrying, and burdening. However, the student did not find those kinds of experiences when entering senior high school. The anxiety existed, but the teachers teach them patiently.

During my 11 years of learning at school, I feel that the teachers in this senior high are the most patient of all. When I was in elementary school and junior high school, I was so afraid when the teachers entered the class. We had to prepare and thought about many things, such as "Will I get punished because I can't answer the question?" or "Do I bring all the books for today?" or "Do I understand today's material?", and many others. I felt burdened at school. However, I don't feel that way anymore. Indeed, I don't hesitate to ask because the teachers in senior high are serious yet relaxed. I understand that the different teaching style is not a problem because they have the same purpose. But I feel more comfortable if I can learn without thinking too much about everything and without fear(P3, 24-33). 
P3 and P10 reported that they maintain their learning enthusiasm because the teachers are amusing and humorous. In addition, the class is not tense, and the teachers do not give them many assignments.

The teachers here are entertaining us with their senses of humor in the classroom.

After spending an entire day learning in the class, they can make us enthusiastic and less sleepy (P3, 34036). More relaxed teaching method, few tasks, and attractive teaching style (P10, 30-32).

Moreover, the step-by-step learning, simple language, and quiz help students feel comfortable in learning.

Mrs. [teacher's name] explained the material in simple and comprehensible words. It's easy to understand the new terms in the discussed material (P1, 6163). She can deliver the material appropriately, ensuring that the students understand what she explains (P2, 5-7). She [teacher's name] teaches briefly, but it includes all the materials. Besides, the quizzes are interesting, so learning history is like playing a game (P2, 12-14).

\section{Fun and supportive peers}

For adolescents, classmates play an important role in establishing their well-being. Eight students mentioned that their classmates are influential in maintaining their motivation to learn, bringing joy and comfort to the school.

The most impressive experience is when I met with friends having the same vibes. When I was in junior high, I was introverted, and I didn't have many friends. I didn't like socializing nor joining an organization. I only had three friends; for one and many reasons, I limited myself from making friends. In school now, I have more friends that bring a positive impact on me. They do not discriminate others and befriend everyone. Besides, I learn to get out of my comfort one; I learn to know people, I want to join the school organization and go around with my friends. Weird as it may seem, but I never did those before entering senior high. I enjoy my life in senior high with the many fun events, supportive environment. I enjoy the learning process, although it is now carried out online (P3, 2-13).

For P3, the experiences gained with peers during high school create a comfortable and enjoyable learning environment at school. As a result, they participated in the school activities and enjoyed the learning process. Similarly, the experiences influence the students, although the learning is now conducted online. The related experience was also shared by P1 in the interview. 
The experience that I like most from the school is when joining the Javanese short story writing competition. During the preparation, I met with cool seniors and teachers. Two of my seniors are fluent in Javanese; they use it in daily communication and create and perform Javanese art on stage. The experiences make me more comfortable and motivated in learning up to now (during online learning) (P1, 2-6).

About the importance of fun and supportive peers, some respondents stated that while in high school (although it was before the pandemic), the experiences affect their life. It allows them to stay connected with the school environment and teachers at school. Therefore, online learning due to the pandemic does not eliminate their learning motivation. Indeed, they are willing to participate in academic activities. Further, they are satisfied with the school service. P2 and P11 added the information as follow:

It's an amazing experience that I could share with friendly seniors, finding solutions together when facing an obstacle or a problem. It is fun. It opens my mind little by little, changes my mindset, and helps me find new things, such as administrative matters, organizational leadership, new friends, and other experiences. I may not repeat them in the future (P2, 2-14). I made many acquaintances in the program, shared new experiences, and told stories with each other $(P 11,2-6)$.

\section{Discussion and Conclusion}

The research is aimed to explore the students' experience in finding the aspects influencing their well-being in online learning during the covid-19 pandemic. The results indicated that concerned teachers, enjoyable and less burdening learning, fun, and supportive peers are three resources of the students' well-being. In general, the results confirmed the previous studies mention that students' motivation and engagement are influenced by several contextual factors, such as supports from teachers and peers(Lietaert et al., 2015). Teacher's support is one crucial factor because they help students develop their motivation at school(Ishak \& Suyatno, 2020; Mardati et al., 2019;Roorda et al., 2018; Suyatno et al., 2019; Wang, 2014).The three dimensions of teachers, such as autonomous, structural, and engagement supports(Lietaert et al., 2015;Roorda et al., 2011), fulfill the students' psychological needs. More specifically, it promotes positive learning and effective teaching strategies necessary to face the challenges during the pandemic.

As confirmed by all respondents, $100 \%$ agreed that concerned teachers become the primary source of student well-being. They encourage the students to participate in various academic activities at school. They also help students to feel comfortable in learning. The facts support the previous findings, explaining that teachers' concern and attention affected the student well-being(Klem \& Connell, 2004;Lavy \& Naama-Ghanayim, 2020;Reddy et al., 2003; Roorda et al., 2011; Suyatno et al., 2020;Wubbels et al., 2016). Care is "emotion, bond, 
and behavior manifestation around us"(Mayseless, 2015, p. 1). The term concern is conceptualized as the feeling, motivation, and behavior reflecting the awareness of others' feelings and needs(Mayseless, 2015). Forms of teachers' concern include affection(Goldstein, 2002), closeness with students(Mayseless, 2015; Suyatno et al., 2019), openness towards students' needs, and empathy(Noddings, 2012).Students who feel noticed and taken care of by the teachers will develop a sense of security(Noddings, 2006, 2012). Therefore, teachers' concern is the most important component affecting the students' development(Lavy \& Naama-Ghanayim, 2020).Besides, it is also related to self-esteem, well-being, and school participation(Roorda et al., 2011).

The teacher's concern is related to the students' mental development during their adolescent period.Bowlby (2005)and Shaver and Mikulincer (2009)stated that adolescents who feel cared for by others tend to have better self-esteem and a sense of security. In an educational environment, the condition encourages them to get out of their comfort zone and face the uncertain reality. A sense of security is established when students feel cared for by the adults around them, especially their teachers(Mayseless, 2015;Shaver \& Mikulincer, 2009). The need for attention is also significant for the students(Lavy \& Naama-Ghanayim, 2020)because they are in a vulnerable period(Kärnä et al., 2010).

The second finding mentioned that student well-being is established when students follow the enjoyable and less burdening classes. It means that they can enjoy the learning activities with the teacher. The class is serious yet relaxing, not giving many tasks, complete with various ice-breakers that prevent students' boredom and lead to learning comfort. Seligman et al. (2009)stated that learning fulfilling the indicators is related to the student well-being; students participate in the academic activities while maintaining the optimal outcome. The teacher's mental condition also influences well-being. For example, teachers who are enthusiastic and pleasing increase the students' motivation, engagement, and better learning outcome(Keller et al., 2014; Kunter et al., 2013), fun and comfortable learning(Becker et al., 2014), and students' academic control and achievement(Muntaner-Mas et al., 2017).

The third finding showed that student well-being is formed because students have fun and supportive peers. For students, classmates are the leading social network they find on their own, ones whom they spend most of their time with(Hofferth\& Sandberg, 2001;Larson, 2001). The peers' well-being influences theirs. In general, the findings support the ones byKing and Datu (2017), mentioning that classmates can transmit social well-being. Student well-being also depends on the well-being of other people existing within the network(Fowler $\&$ Christakis, 2009).Similarly, the current study confirms several views in well-being theories emphasizing social context as an aspect of establishing well-being (Tian et al., 2015). Besides, other research mentioned that well-being could be transmitted through peers, although they are not specifically learning in the same class(Dishion\& Tipsord, 2011; Giletta et al., 2013;Parker et al., 2021; Parker et al., 2015). Some studies mentioned that well-being 
could spread through online networking and peer groups(Eyre et al., 2017;Giletta et al., 2013;Parker et al., 2021).

\section{Suggestions}

The findings become an important reference for several parties, especially for principals as the highest policymaker in the academic unit at school, teachers as the controller and classroom manager, and teacher training institution (LPTK) as the institutions responsible for preparing the pre-service teachers. For principals, they need to identify, map, and establish a policy related to the components of student well-being. The policies and programs implemented during online learning in the covid-19 pandemic need to be oriented towards improvingthe teachers' soft skills. Therefore, they become more concerned about the students in the class. Besides, they will develop the ability to implement fun and easy learning.For example, online learning needs to be directed towards qualitative achievement since the quantitative ones tend to burden the students. In addition, the principals with the teachers need to create a condition where peers' social networking in the classroom setting can support the students' learning. The findings suggest that teacherscontinue to improve their soft skills, allowing them to show concern and devotion while helping them during online learning. Further, the teacher training institution (LPTK) needs to re-direct the curriculum so that the pre-service teachers have the competence and experience in conducting enjoyable learning.

\section{Acknowledgment}

We would like to express our gratitude to Universitas Ahmad Dahlan for funding the research in the form of an internal grant of Research and Community Service Institution (LPPM) UAD with the contract number ofPD-360/SP3/LPPM-UAD/V/2021

\section{References}

1. Adedoyin, O. B., \& Soykan, E. (2020). Covid-19 pandemic and online learning: the challenges and opportunities. Interactive Learning Environments, O(0), 1-13. https://doi.org/10.1080/10494820.2020.1813180

2. Adnan, M., \& Boz, B. (2015). Faculty Members' Perspectives on Teaching Mathematics Online: Does Prior Online Learning Experience Count? Öğretim Üyelerinin Çevrimiçi Matematik Öğretimine Bakışları: Çevrimiçi Öğrenme Deneyimi Bakış Açısını Değiştiriyor Mu? Turkish Online Journal of Qualitative Inquiry, 6(61), 21-39.

3. Astuti, I. A. D., Bhakti, Y. B., Sumarni, R. A., Sulisworo, D., \& Toifur, M. (2021). Flipped Classroom and Kahoot in Physics Learning: Improving Students' Motivation Learning. International Journal of Educational Management and Innovation, 2(2), 175. https://doi.org/10.12928/ijemi.v2i2.3491

4. Barboni, L. (2019). From shifting earth to shifting paradigms: How webex helped our university overcome an earthquake. CISCO, Upshot By Influitive.

5. Baticulon, R. E. (2021). Barriers to online learning in the time of COVID-19 (Vol. 
2019, Issue March 2020). https://doi.org/10.1101/2020.07.16.20155747

6. Becker, B., \& Eva, S., Thomas, G., Morger, V., \& Ranellucci, J. (2014). The importance of teachers ' emotions and instructional behavior for their students ' emotions - An experience sampling analysis The Importance of Teachers 'Emotions and Instructional Behavior for Their Students 'Emotions - An Experience Sampling Analys. 15-26.

7. Bhanot, D., \& Verma, S. K. (2020). Lived experiences of the Indian stigmatized group in reference to socio-political empowerment: A phenomenological approach. Qualitative Report, 25(6), 1414-1435. https://doi.org/10.46743/2160-3715/2020.4143

8. Bowlby, J. (2005). A secure base: Clinical applications of attachment theory (Vol. 393). Taylor \& Francis.

9. Bozkurt, A., \& Sharma, R. C. (2020). Emergency remote teaching in a time of global crisis due to CoronaVirus pandemic. Asian Journal of Distance Education, 15(1), i-vi.

10. Brooks, J., King, N., \& Tomkins, L. (2017). Using Interpretative Phenomenological Psychology in Organisational Research with Working Carers. Applied Qualitative Research in Psychology, 86-100. https://doi.org/10.1057/978-1-137-35913-1_5

11. Carey, K. (2020). Everybody ready for the big migration to online college? Actually, No. The New York Times, 13.

12. Cassidy, E., Reynolds, F., Naylor, S., \& De Souza, L. (2011). Using interpretative phenomenological analysis to inform physiotherapy practice: An introduction with reference to the lived experience of cerebellar ataxia. Physiotherapy Theory and Practice, 27(4), 263-277. https://doi.org/10.3109/09593985.2010.488278

13. Childs, S., Blenkinsopp, E., Hall, A., \& Walton, G. (2005). Effective e-learning for health professionals and students--barriers and their solutions. A systematic review of the literature--findings from the HeXL project. Health Information and Libraries Journal, 22 Suppl 2, 20-32. https://doi.org/10.1111/j.1470-3327.2005.00614.x

14. Chiu, T. K. F. (2021). Applying the self-determination theory (SDT) to explain student engagement in online learning during the COVID-19 pandemic. Journal of Research on Technology in Education, $0(0)$, 1-17. https://doi.org/10.1080/15391523.2021.1891998

15. Creswell, J. W. (2012). Educational Research: Planning, Conducting, and Evaluating Quantitative and Qualitative (4th ed.). Pearson Education Inc.

16. Daroedono, E., Forman E. S., Alfarabi, M., Cing, J. M., Arodes, E. S., Sirait, R. H., Suryowati, T., Sunarti, L. S., Ahmad, L. N., Wiyanto, M., Kurniaty, L., \& Hutabarat, R. S. O. (2020). The impact of COVID-19 on medical education: Our students perception on practice of online education. Pakistan Journal of Medical and Health Sciences, 14(4), 766-768.

17. Di Pietro, G. (2018). The academic impact of natural disasters: evidence from L'Aquila earthquake. Education Economics, 26(1), 62-77. https://doi.org/10.1080/09645292.2017.1394984

18. Diener, E., \& Chan, M. Y. (2011). Happy People Live Longer: Subjective Well-Being Contributes to Health and Longevity. Applied Psychology: Health and Well-Being, 3(1), 1-43. https://doi.org/10.1111/j.1758-0854.2010.01045.x

19. Dishion, T. J., \& Tipsord, J. M. (2011). Peer contagion in child and adolescent social 
and emotional development. Annual Review of Psychology,62, 189-214.

20. Domitrovich, C. E., Durlak, J. A., Staley, K. C., \& Weissberg, R. P. (2017). SocialEmotional competence: An essential factor for promoting positive adjustment and reducing risk in school children. Child Development, 88(2), 408-416. https://doi.org/10.1111/cdev.12739

21. Eyre, R. W., House, T., Hill, E. M., \& Griffiths, F. E. (2017). Spreading of components of mood in adolescent social networks. Royal Society Open Science, 4(9). https://doi.org/10.1098/rsos.170336

22. Favale, T., Soro, F., Trevisan, M., Drago, I., \& Mellia, M. (2020). Campus traffic and e-Learning during COVID-19 pandemic. Computer Networks, 176(April). https://doi.org/10.1016/j.comnet.2020.107290

23. Fedynich, L. V. (2014). Teaching beyond the classroom walls: The pros and cons of cyber learning. Journal of Instructional Pedagogies, 13, 1-7. http://aabri.comwww.aabri.com/manuscripts/131701.pdf

24. Fishbane, L., \& Tomer, A. (2020). As classes move online during COVID-19, what are disconnected students to do? Brookings.

25. Fogarty, G. J., Davies, J. E., Maccann, C., \& Roberts, R. D. (2014). Self- versus parent-ratings of industriousness, affect, and life satisfaction in relation to academic outcomes. British Journal of Educational Psychology, 84(2), 281-293. https://doi.org/10.1111/bjep.12024

26. Fowler, J. H., \& Christakis, N. A. (2009). Dynamic spread of happiness in a large social network: Longitudinal analysis over 20 years in the Framingham Heart Study. BMJ (Online), 338(7685), 23-26. https://doi.org/10.1136/bmj.a2338

27. Frehywot, S., Vovides, Y., Talib, Z., Mikhail, N., Ross, H., Wohltjen, H., Bedada, S., Korhumel, K., Koumare, A. K., \& Scott, J. (2013). E-learning in medical education in resource constrained low- and middle-income countries. Human Resources for Health, 11(1), 1-15. https://doi.org/10.1186/1478-4491-11-4

28. Giletta, M., Burk, W. J., Scholte, R. H., Engels, R. C., \& Prinstein, M. J. (2013). Direct and indirect peer socialization of adolescent nonsuicidal self-injury. Journal of Research on Adolescence, 23(3), 450-463.

29. Goldstein, L. S. (2002). Reclaiming caring in teaching and teacher education.

30. Hidayati, D., \& Saputra, W. A. (2020). Implementation of online learning during the covid-19 epidemic in Indonesia: Assessment of higher education students' use and implementation of online learning technology. Universal Journal of Educational Research, 8(10), 4514-4519. https://doi.org/10.13189/ujer.2020.081019

31. Hofferth, S. L., \& Sandberg, J. F. (2001). How American children spend their time. Journal of Marriage and Family, 63, 295-308.

32. Iqbal, N., Srivastava, S., \& Dar, I. (2020). An Interpretative Phenomenological Inquiry into Experience, Expression, and Effect of Gratitude among Males and Females. The Qualitative Report, 25(9), 3425-3439. https://doi.org/10.46743/21603715/2020.4406

33. Ishak, S. N. S., \& Suyatno. (2020). Teacher performance, parent's role, and student learning outcomes in muhammadiyah junior high school. Universal Journal of Educational Research, 8(2), 529-539. https://doi.org/10.13189/ujer.2020.080224

34. Kärnä, A., Voeten, M., Poskiparta, E., \& Salmivalli, C. (2010). Vulnerable Children 
Student Well-Being in Online Learning during the Covid-19 Pandemic:

Voice in the Field

in Varying Classroom Contexts : Bystanders ' Behaviors Moderate the Effects of Risk Factors on Victimization Author ( s ): Antti Kärnä , Marinus Voeten, Elisa Poskiparta and Christina Salmivalli Source: Merrill-Palmer Quarterly, Vol. Merrill-Palmer Quarterly, 56(3), 261-282.

35. Keller, M. M., Goetz, T., Becker, E. S., Morger, V., \& Hensley, L. (2014). Feeling and showing: A new conceptualization of dispositional teacher enthusiasm and its relation to students' interest. Learning and Instruction, 33, 29-38. https://doi.org/10.1016/j.learninstruc.2014.03.001

36. Kim, J. (2020). Learning and Teaching Online During Covid-19: Experiences of Student Teachers in an Early Childhood Education Practicum. International Journal of Early Childhood, 52(2), 145-158. https://doi.org/10.1007/s13158-020-00272-6

37. King, R. B., \& Datu, J. A. (2017). Happy classes make happy students: Classmates' well-being predicts individual student well-being. Journal of School Psychology, 65(May), 116-128. https://doi.org/10.1016/j.jsp.2017.07.004

38. Klem, A. M., \& Connell, J. P. (2004). Linking Teacher Support to Student Engagement and Achievement Adena M. Klem, James P. Connell A. Journal of School Health, 74(7), 263-273.

39. Kunter, M., Klusmann, U., Baumert, J., Richter, D., Voss, T., \& Hachfeld, A. (2013). Professional competence of teachers: Effects on instructional quality and student development. Journal of Educational Psychology, 105(3), 805-820. https://doi.org/10.1037/a0032583

40. Lan, X., \& Moscardino, U. (2019). Direct and interactive effects of perceived teacherstudent relationship and grit on student wellbeing among stay-behind early adolescents in urban China. Learning and Individual Differences, 69(June 2018), 129-137. https://doi.org/10.1016/j.lindif.2018.12.003

41. Langdridge, D. (2007). Phenomenological psychology: Theory, research and method. Upple Saddle River, NJ: Pearson Education.

42. Larkin, M., Watts, S., \& Clifton, E. (2006). Giving voice and making sense in interpretative phenomenological analysis. Qualitative Research in Psychology, 3(2), 102-120. https://doi.org/10.1191/1478088706qp062oa

43. Larson, R. W. (2001). How U.S. Children and adolescents spend time: What it does (and doesn't) tell us about their development. Current Directions in Psychological Science, 10(5), 160-164. https://doi.org/10.1111/1467-8721.00139

44. Lavy, S., \& Naama-Ghanayim, E. (2020). Why care about caring? Linking teachers' caring and sense of meaning at work with students' self-esteem, well-being, and school engagement. Teaching and Teacher Education, 91(May). https://doi.org/10.1016/j.tate.2020.103046

45. Leszczyński, P., Charuta, A., Łaziuk, B., Gałązkowski, R., Wejnarski, A., Roszak, M., \& Kołodziejczak, B. (2018). Multimedia and interactivity in distance learning of resuscitation guidelines: a randomised controlled trial. Interactive Learning Environments, 26(2), 151-162. https://doi.org/10.1080/10494820.2017.1337035

46. Lewis, A. D., Huebner, E. S., Malone, P. S., \& Valois, R. F. (2011). Life Satisfaction and Student Engagement in Adolescents. Journal of Youth and Adolescence, 40(3), 249-262. https://doi.org/10.1007/s10964-010-9517-6 
47. Lietaert, S., Roorda, D., Laevers, F., Verschueren, K., \& De Fraine, B. (2015). The gender gap in student engagement: The role of teachers' autonomy support, structure, and involvement. British Journal of Educational Psychology, 85(4), 498-518. https://doi.org/10.1111/bjep.12095

48. Mardati, A., \& Suyatno, Pambudi, D. I. (2019). The influence of teacher leadership and teacher values on students learning readiness at junior high school in pangkalpinang ci ty. International Journal of Scientific and Technology Research, 8(10), 3311-3416.

49. Martin, A. (2020). How to optimize online learning in the age of coronavirus (COVID-19): A 5-point guide for educators. Journal of Chemical Information and Modeling, 53(9), 1689-1699. https://newsroom.unsw.edu.au/news/social-affairs/howoptimise-online-learning-age- coronavirus\%0A

50. Mayseless, O. (2015). The caring motivation: An integrated theory. Oxford University Press.

51. Means, B., Toyama, Y., Murphy, R., \& Baki, M. (2013). The effectiveness of online and blended learning: A meta-analysis of the empirical literature. Teachers College Record, 115(3).

52. Modesto, O. (2020). A Phenomenological Study of Filipino Immigrant Teachers in South Texas. The Qualitative Report, 25(8), 3149-3162. https://doi.org/10.46743/2160-3715/2020.4225

53. Mukhtar, K., Javed, K., Arooj, M., \& Sethi, A. (2020). Advantages, limitations and recommendations for online learning during covid-19 pandemic era. Pakistan Journal of Medical Sciences, 36(COVID19-S4), $\quad$ S27-S31. https://doi.org/10.12669/pjms.36.COVID19-S4.2785

54. Muntaner-Mas, A., Vidal-Conti, J., Sesé, A., \& Palou, P. (2017). Teaching skills, students' emotions, perceived control and academic achievement in university students: A SEM approach. Teaching and Teacher Education, 67, 1-8. https://doi.org/10.1016/j.tate.2017.05.013

55. Noddings, N. (2006). Educational leaders as caring teachers. School Leadership and Management, 26(4), 339-345. https://doi.org/10.1080/13632430600886848

56. Noddings, N. (2012). The caring relation in teaching. Oxford Review of Education,38(6), 771-781.

57. Noon, E. J. (2018). Interpretive Phenomenological Analysis: An Appropriate Methodology for Educational Research? Journal of Perspectives in Applied Academic Practice, 6(1), 75-83. https://doi.org/10.14297/jpaap.v6i1.304

58. O’Doherty, D., Dromey, M., Lougheed, J., Hannigan, A., Last, J. \& McGrath, D. (2018). Aneurismas aorticos gigantes. El Día Médico, 20(22), 832-834.

59. Oktaria, A. A., \& Rahmayadevi, L. (2021). Students' Perceptions of Using Google Classroom During the Covid-19 Pandemicc. International Journal of Educational Management and Innovation, 2(2), 153. https://doi.org/10.12928/ijemi.v2i2.3439

60. Parker, P. D., Ciarrochi, J., Heaven, P., \& Marshall, S. (2021). Hope , Friends, and Subjective Well-Being : A Social Network Approach to Peer Group Contextual Effects Author ( s ): Philip D. Parker, Joseph Ciarrochi, Patrick Heaven, Sarah Marshall, Baljinder Sahdra and Noona Kiuru Source : Child Development, Vo. 86(2), 642-650. https://doi.org/10.1111/cdev.12308 
61. Parkes, M., Stein, S., \& Reading, C. (2015). Student preparedness for university elearning environments. Internet and Higher Education, 25(October), 1-10. https://doi.org/10.1016/j.iheduc.2014.10.002

62. Patton, M. Q. (2002). Qualitative research and evaluation methods. Thousand Oaks, CA: Sage.

63. Pokhrel, S., \& Chhetri, R. (2021). A Literature Review on Impact of COVID-19 Pandemic on Teaching and Learning. Higher Education for the Future, 8(1), 133141. https://doi.org/10.1177/2347631120983481

64. Ravichandran, P., \& Shah, A. K. (2020). Shadow pandemic: Domestic violence and child abuse during the COVID-19 lockdown in India. International Journal of Research in Medical Sciences, 8(8), 3118.

65. Reddy, R., Rhodes, J. E., \& Mulhall, P. (2003). The influence of teacher support on student adjustment in the middle school years: A latent growth curve study. Development and Psychopathology, 15(1), 119-138. https://doi.org/10.1017/S0954579403000075

66. Ribeiro, R. (2020). How university faculty embraced the remote learning shift. EdTech Magazine.

67. Roorda, D. L., Koomen, H. M., Spilt, J. L., \& Oort, F. J. (2018). Running Head: 21.

68. Roorda, D. L., Koomen, H. M. Y., Spilt, J. L., \& Oort, F. J. (2011). The influence of affective teacher-student relationships on students' school engagement and achievement: A meta-analytic approach. Review of Educational Research, 81(4), 493529. https://doi.org/10.3102/0034654311421793

69. Ryan, R. M., \& Deci, E. L. (2020). Intrinsic and extrinsic motivation from a selfdetermination theory perspective: Definitions, theory, practices, and future directions. $\begin{array}{lll}\text { Contemporary Educational Pschology, } & \text { 61(April). }\end{array}$ https://doi.org/10.1016/j.cedpsych.2020.101860

70. Scrimin, S., Moscardino, U., Altoè, G., \& Mason, L. (2016). Effects of perceived school well-being and negative emotionality on students' attentional bias for academic stressors. British Journal of Educational Psychology, 86(2), 278-295. https://doi.org/10.1111/bjep.12104

71. Seligman, M. E. P., Ernst, R. M., Gillham, J., Reivich, K., \& Linkins, M. (2009). Positive education: Positive psychology and classroom interventions. Oxford Review of Education, 35(3), 293-311. https://doi.org/10.1080/03054980902934563

72. Shaver, P. R., \& Mikulincer, M. (2009). Attachment Theory, Individual Psychodynamics, and Relationship Functioning. The Cambridge Handbook of Personal Relationships, 251-272. https://doi.org/10.1017/cbo9780511606632.015

73. Sintema, E. J. (2020). Effect of COVID-19 on the performance of grade 12 students: Implications for STEM education. Eurasia Journal of Mathematics, Science and Technology Education, 16(7), 1-6. https://doi.org/10.29333/EJMSTE/7893

74. Smedley, J. (2010). Modelling the impact of knowledge management using technology. OR Insight, 23(4), 233-250. https://doi.org/10.1057/ori.2010.11

75. Smith, J. A., \& Eatough, V. (2006). Interpretative phenomenological analysis. In G. M. \&\& J. A. S. (Ed. . Breakwell, S. Hammond, C. Fife-Schaw (Eds.), Research methods in psychology (3rd ed.) (pp. 322-341). Thousand Oaks, CA: Sage. 
76. Smith, J. A., Flowers, P., \& Larkin, M. (2009). Interpretative phenomenological analysis: Theory, method, and research. Sage.

77. Smith, J. A. \& Osborn, M. (2008). Interpretative Phenomenological Analysis. Los Angeles, CA: SAGE Publications. In I. J. A. Smith \& (Ed.) (Eds.), Qualitative psychology: A practical guide to research methods (p. (2nd ed., pp. 53-80).).

78. Smith, J. A., \&, \& Osborn, M. (2015). Interpretative phenomenological analysis as a useful methodology for research on the lived experience of pain. British Journal of Pain, 9(1), 41-42. https://doi.org/10.1177/2049463714541642

79. Suyatno, S., Jumintono, J., Pambudi, D.I., Mardati, A. \& Wantini, W. (2019). Strategy of Values Education In Indonesian Education System. International Journal of Instruction, 12(1), 607-624.

80. Suyatno, Pambudi, D. I., Amurdawati, G., Wantini, \& Ningrum, M. V. R. (2020). Factors affecting the meaning in life of teachers. Pedagogika, 139(3), 52-72. https://doi.org/10.15823/p.2020.139.3

81. Suyatno, Pambudi, D. I., Mardati, A., Wantini, Nuraini, E., \& Yoyo. (2019). The education values of Indonesian teachers: Origin, importance, and its impact on their teaching. International Journal of Instruction, 12(3), 633-650. https://doi.org/10.29333/iji.2019.12338a

82. Sweetman, D., Badiee, M., \& Creswell, J. W. (2010). Use of the transformative framework in mixed methods studies. Qualitative Inquiry, 16(6), 441-454. https://doi.org/10.1177/1077800410364610

83. Tian, L., Zhao, J., \& Huebner, E. S. (2015). School-related social support and subjective well-being in school among adolescents: The role of self-system factors. Journal of Adolescence, 45(December 2015), 138-148. https://doi.org/10.1016/j.adolescence.2015.09.003

84. Tuominen-Soini, H., Salmela-Aro, K., \& Niemivirta, M. (2012). Achievement goal orientations and academic well-being across the transition to upper secondary education. Learning and Individual Differences, 22(3), 290-305. https://doi.org/10.1016/j.lindif.2012.01.002

85. UNESCO. (2020). Education: From disruption to recovery.

86. Vijay Govindarajan, \& Anup Srivastava. (2020). What the Shift to Virtual Learning Could Mean for the Future of Higher Ed. Harvard Business Review. https://hbr.org/2020/03/what-the-shift-to-virtual-learning-could-mean-for-the-futureof-higher-ed

87. Wagner, N., Hassanein, K., Head, M., Wagner, N., Hassanein, K., \& Head, M. (2008). International Forum of Educational Technology \& Society Who is responsible for E-Learning Success in Higher Education? A Stakeholders ' Analysis Published by: International Forum of Educational Technology \& Society Who is responsible for E-Learning Succ. International Forum of Educational Technology \& Society, 11(3), 26-36. https://www.jstor.org/stable/10.2307/jeductechsoci.11.3.26

88. Wang, S. X. (2014). The effect of parental migration on the educational attainment of their left-behind children in rural China. The BE Journal of Economic Analysis \& Policy, 14(3), 1037-1080.

89. Wedenoja, L. (2020). What to expect when you weren't expecting online classes. Rockefeller Institute of Government. 
90. Wedlock, M. (2016). "You kind of pull back the layers": The experience of interprofessional supervision with Educational Psychologists. (Doctoral dissertation, University of Essex \& Tavistock and Portman NHS Trust).

91. Whalen, B. (2020). Education abroad in a post-COVID-19 world. Inside Higher Ed.

92. Wright, T. A., \& Cropanzano, R. (2000). Psychological well-being and job satisfaction as predictors of job performance. Journal of Occupational Health Psychology, 5(1), 84-94. https://doi.org/10.1037/1076-8998.5.1.84

93. Wubbels, T., Brekelmans, M., \& Mainhard, T. (2016). Teacher-student relationships and student achievement. In Handbook of social influences in school contexts. Routledge.

94. Yilmaz, A. B. (2019). Distance and Face-To-Face Students' Perceptions Towards Distance Education: a Comparative Metaphorical Study. Turkish Online Journal of Distance Education, January, 191-207. https://orcid.org/0000-0002-9971-2440

95. Zakaria, Z. (2021). Online Learning in Master Educational Administration Program: Student'S Perception. International Journal of Educational Management and Innovation, 2(2), 240. https://doi.org/10.12928/ijemi.v2i2.3749

96. Zimmerman, J. (2020). Coronavirus and the great online-learning experiment. Chronicle of Higher Education, 37-47.

97. Zins, J. E., \& Elias, M. J. (2007). Social and emotional learning: Promoting the development of all students. Journal of Educational and Psychological Consultation, 17(2-3), 233-255. https://doi.org/10.1080/10474410701413152 